\title{
Herbivore Fish as Sustainable Alternative for Nutrition Security: Food Habits and Nutritional Composition of the Acha Fish (Medialuna Ancietae) in Northern Chile.
}

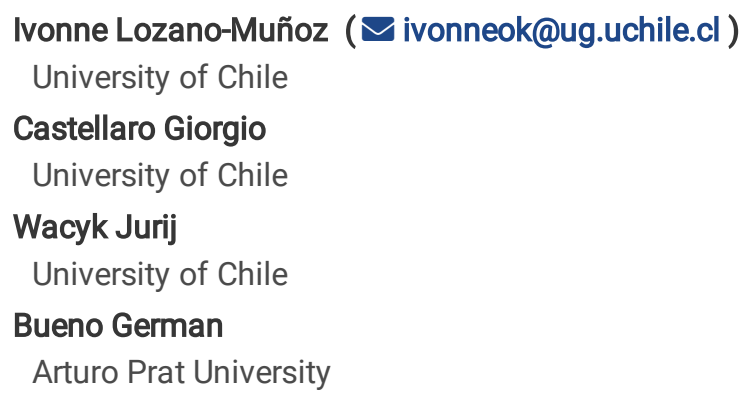

Research Article

Keywords: Herbivores fish, nutrition security, sustainable aquaculture, macroalgae, Medialuna ancietae

Posted Date: July 12th, 2021

DOI: https://doi.org/10.21203/rs.3.rs-661527/v1

License: (c) (i) This work is licensed under a Creative Commons Attribution 4.0 International License. Read Full License 


\section{Abstract}

Sustainability in aquaculture is a necessity of the future, not only as the most promising means of supplying the protein that the world will require to feed its growing population but to offer needed conservation of the world's ocean resources. The use of wild fish inputs in farm-raised fish outputs has been a primary concern of sustainability in aquaculture production. Herbivorous fish are more efficient convertors of protein into fish flesh. Species of the genus Medialuna fish have been reported as a fast-growing, short-lived species. The endemic Acha fish (Medialuna ancietae) in the Northern part of Chile is an over-exploited fish that has been associated with aquatic vegetation as a food source. We studied the eating habits and nutritional composition of $M$. ancietae. For this, we developed a reference collection of marine macroalga (epidermis and nutritional composition) observed in the diet of individuals of this species for the study of digestive material. More than $90 \%$ of the components found were marine macroalgae, indicating that $M$. ancietae is an herbivorous fish. Compared to non-herbivorous fish our results showed that most of the nutrients present in the Medialuna diet are found at much lower levels including n-3 long-chain polyunsaturated fatty acids (49.7\%) and protein (13-60\%). M. ancietae meat provides essential components of human nutrition with a significant protein content $(18.99 \pm 0.26 \%)$ and the presence of $n-3$ long-chain polyunsaturated fatty acids. Most fed aquaculture non-herbivorous species rely on wild-captured fish for these essential nutrients, while $M$. ancietae can obtain and has the ability to concentrate them from potentially cultivable macroalgae. $M$. ancietae has potential for a sustainable aquaculture production as a contribution to nutrition security and re-stocking of wild populations.

\section{Introduction}

Aquaculture is currently the fastest growing global animal food production sector and is a key future contributor to food security; most fed aquaculture species rely on wild captured fish for essential fatty acids and micronutrients, as the fastest-growing food sector fed aquaculture demand exceeds ecological limits of these population of wild fish [1, 2]. Aquaculture is the biggest global consumer of fishmeal (70\%) and fish oil (73\%); within the next decade, fish oil production is unlikely to meet the required quantities for aquaculture [3]. As a result, the use of other alternative inputs with nutritionally equivalent profiles, such as algae, will be necessary to stabilize access to fish long-chain omega-e fatty acids. The use of non-carnivorous aquaculture is also an alternative to this problem and a good strategy for sustainable aquaculture [4]. Non-carnivorous or herbivorous fishes also allow for a more productive algal community by decreasing the self-shading of algae, as well as increasing the local nutrient input via herbivore excretions; herbivorous fishes can be abundant in temperate rocky-reef habitats [5] and have been reported as short-lived and fast-growing species [6]. Herbivorous fishes have a specialized morphology of the digestive tract with the ability to assimilate seaweed compounds and to grow on a seaweed diet (stomach content with more than $50 \%$ plant material). The stomachs of several species of herbivorous fishes are muscular and function as gizzards to grind filamentous algae and diatoms into fine particles for chemical breakdown and subsequent absorption [7].

In Chile, the cultivation of native marine fish is an incipient issue. Research into the cultivation of native marine fish began with capturing wild specimens, including Merluccius australis, Cilus gilberti, Seriola lalandi, Paralichthys adpersus, and Medialuna ancietae [8]. M. ancietae (Acha fish) is a native species with potential for aquaculture and repopulation. $M$. ancietae lives mainly in the waters of the rocky coasts of Northern Chile and Peru, is found in wide and deep caletones, breaking from rocky beaches [9]. The catches of this species have decreased from 9000 tons per year in the 1980 s to less than 100 tons per year by the middle of the 2000s. Currently, $M$. ancietae is virtually never encountered during spearfishing [10]. The local demand for the quality of its meat, the no size or catch regulations, and its decrease in catches make this species an interesting alternative to develop its aquaculture. M. ancietae is an important resource for artisanal and sport fishing in the north of Chile, but unfortunately, it shows signs of a decline in its abundance and the sizes of the fish caught [9], which is why initiatives have been developed to cultivate it for commercial purposes and of possible repopulation actions.

M. ancietae can be found with difficulty in some parts of northern Chile, especially on the coasts of the small town called Pisagua $\left(19^{\circ} 36^{\prime} 22,57\right.$ 'S, $70^{\circ} 12^{\prime} 09,96$ 'W). It is characterized by the presence of large cliffs and mountain ranges, typical of the coastline coastal region I (Tarapaca region). The intertidal zone of this locality is conditioned by the existence of cliffs with a narrow Lessonia berteroana (formerly Lessonia nigrescens) belt that varies between 0.5 and $1.0 \mathrm{~m}$. Among the inter-disk spaces, nine taxa have been reported (two algae and seven invertebrates). The algae present correspond to calcareous with $66 \%$ and Corallina sp with $1 \%$ [11]. The fauna associated with this environment mainly comprises Fissurella $s p$ and Chiton $s p$, followed by Actinia and $H$. helianthus. There is a specific dominance of Fissurella spp (27\%) [12]. The black snail Tegula atra (Lesson 1830) is a gastropod of the Trochidae family, which is distributed throughout the Southeast Pacific from Pacasmayo, Peru $\left(7^{\circ} 24^{\prime} \mathrm{S}\right)$ to the Strait of Magellan, Chile $\left(53^{\circ} 28^{\prime} \mathrm{S}\right)$. T. atra has been observed associated with different species of macroalgae of the order Laminariales. In northern Chile, $T$. atra is found in intertidal environments next to Lessonia berteroana and, in subtidal areas, next to Lessonia trabeculata [11]. 
For efficient culture and management of fish, knowledge on food and feeding habits is of immense importance, and this is intimately associated with the ecological niche they occupy in the natural environment [13]. Good reproductive performance for the successful production of juveniles is unpredictable and limiting. It has been shown that adequate nutrition and feeding of the breeders is necessary for a good quality of the egg and sperm and the production of seeds, gonadal development, and fecundity, which are affected by certain essential nutrients of the diet, especially HUFA n-3 fatty acids. The lipid and fatty acid composition of the breeders' diet has been identified as the main factor determining the successful reproduction and survival of the offspring. Some fish species will incorporate highly unsaturated fatty acids in the eggs, even during spawning; these highly unsaturated HUFA fatty acids with 20 or more carbon atoms directly affect the maturation of fish and steroidogenesis through their metabolites $[14,15]$.

The knowledge of the feeding behaviors and the diet components are fundamental aspects to be considered when developing feeding plans that contain the profiles of these fatty acids necessary for the species to be tamed for commercial aquaculture and repopulation purposes. Part of these studies can be carried out by analyzing the digestive content with different microhistological techniques that constitute reliable procedures for identifying essential elements in herbivore feeding [16].

This research aimed to study the food habits and nutritional composition of Medialuna ancietae, this work is expected to provide a basis for M. ancietae environmentally sustainable aquaculture production as a contribution to nutrition security and re-stocking purposes in Northern Chile.

\section{Materials And Methods}

\section{Collection of fish}

M. ancietae is an overexploited species. Therefore, its fishing is difficult, and catches are not always successful. Fishing trips were made during 2019. Fishes were caught by free diving using a modified harpoon off the shore of Pisagua (Latitude: $19^{\circ} 00^{\prime} / 20^{\circ} 00^{\prime}$ and Longitude: $\left.69^{\circ} 00^{\prime} / 70^{\circ} 30^{\prime}\right)$, Chile. Morphometric measurements were obtained from each fish, and the stomach was extracted. All samples were transported to our laboratory under ice-storage conditions. All experiments were approved and performed according to guidelines provided by Comité de Bioseguridad y Biocustodia Universidad Arturo Prat, certificate UNAP/VRIIP N003/2018. This study is reported in accordance with ARRIVE guidelines [17].

\section{Collection of reference patterns and Stomach Content Analysis}

From the components commonly observed in the diet by divers in the area of individuals of this species, comparison patterns of epidermis were obtained, organisms were collected manually in the intertidal zone and by diving off the coasts of Pisagua (Latitude: $19^{\circ} 00^{\prime} / 20^{\circ} 00^{\prime}$ and Longitude: $69^{\circ} 00^{\prime} / 70^{\circ} 30^{\prime}$ ) and Iquique (Latitude: -20.2167 , Longitude: $-70.1520^{\circ} 13^{\prime} 0^{\prime \prime}$ South, $70^{\circ} 9^{\prime} 0^{\prime \prime}$ West). The macroalgae species collected were Macrocystis integrifolia, Lessonia berteroana, Corallina officinalis var. chilensis., and Glosophora kunthii.

The samples were dried in the field and fixed with $4 \%$ formalin in seawater [18] after collection or diving. For the transfer to the laboratory in the city of Santiago, the different species of macroalgae belonging to the marine ecosystem of the area were identified. Subsequently, the epidermal tissue was removed from the macroalgae, following the diafanization methodology [16] and the sodium bicarbonate method [19].

\section{The diafanization method.}

the material was boiled in $96 \%$ alcohol for $10 \mathrm{~min}$ at $150^{\circ} \mathrm{C}$, then boiled again in an aqueous solution (1:1) of $96 \%$ alcohol and $5 \%$ sodium hydroxide for another $10 \mathrm{~min}$ in a hot iron at $350^{\circ} \mathrm{C}$ under the hood, to avoid possible inflammations of alcohol and the inhalation of gases. Then, the treated material was deposited on a Petri dish and washed with distilled water until it was cleaned of reagents. Next, a solution of $5 \%$ sodium hypochlorite diluted with $50 \%$ distilled water was applied; they were allowed to stand long enough for them to become transparent $(30 \mathrm{~min})$, permanently monitoring this process. Once the material was rinsed, it was passed through distilled water five times ( 5 min each change) and kept in a $5 \%$ chloral hydrate solution to remove opacity. The material was kept in this solution for $10 \mathrm{~min}$. 


\section{The sodium bicarbonate method}

The material was deposited on a Petri dish, then a solution of $17.5 \%$ of sodium bicarbonate was applied, the macroalgae were soaked for $48 \mathrm{~h}$, then cleared by soaking in a solution of $50 \%$ sodium hypochlorite for $20 \mathrm{~min}$, and then washed with abundant distilled water. Subsequently, histological cuts (transversal) were made in the samples treated. The cuts were made manually with a scalpel, and the sample was deposited on a slide, taking care that the face to be observed is facing up, placing a drop of distilled water and covering the sample with a $24 \times 24 \mathrm{~mm}$ object cover. Epidermis preparations were observed under a microscope (LEICA, DM500 model equipped with ICC50W digital camera) connected to a computer to observe the epidermis on the screen of the same, photographs of all the patterns obtained using a magnification of 40x were taken to the visualization of its histological characteristics. Descriptions and illustrations of the records were made by consultation in bibliographic references [20-23]. The photographs were used for subsequent recognition of stomach contents preparations for botanical determination of their diet.

Stomach content samples were obtained immediately from eight individuals captured. The fish died at the time of capture, so it was not necessary to apply euthanasia. Stomach samples from the caught fish were weighed. Subsequently, the stomach contents were separated macroscopically by taxonomic group, and their weight was recorded. Each taxonomic group was preserved in $10 \%$ formalin. For the microhistological analysis, the material was washed with distilled water, and the diafanization [16] and the sodium bicarbonate [19] method were used for the subsequent observation of the samples in an optical microscope (LEICA, DM500 model equipped with ICC50W digital camera). Images were captured for analysis. In the quantitative analysis of the food components, the gravimetric method (G) and frequency of occurrence (FO) were used. For FO, the number of stomachs containing one or more components of each food category was recorded; this number was then expressed as a percentage of all stomachs [24]. The total weight of each food category is expressed as a percentage of the overall weight of the stomach contents.

\section{Nutritional composition of collected macroalgae, stomach content, and Medialuna a. meat}

Macroalgae and Medialuna a. were collected manually in the intertidal zone and by diving off the coasts of Pisagua (Latitude: $19^{\circ} 00$ ' $/ 20^{\circ} 00^{\prime}$ and Longitude: $69^{\circ} 00^{\prime} / 70^{\circ} 30^{\prime}$ ) and Iquique (Latitude: -20.2167 , Longitude: $-70.1520^{\circ} 13^{\prime} 0{ }^{\prime \prime}$ South, $70^{\circ} 9^{\prime} 0$ " West). The macroalgae species collected were Macrocystis integrifolia, Lessonia berteroana, Corallina officinalis var. chilensis., and Glosophora kunthii.

Macroaalge and Medialuna samples were immediately frozen in liquid nitrogen for transport to the laboratory and subsequent lyophilization. The lyophilized material was used for proximate and fatty acid composition following the recommended methods of the Association of Official Analytical Chemists (AOAC): fatty acid profile [25], crude protein combustion analysis [26] utilizing the calculation $6.25 \times$ nitrogen value, crude fat [27], moisture content [28], ash [29], crude fat [27], sodium and potassium [30], and zinc and calcium [31]. Total carbohydrates were calculated $₫$ by difference", $100 \%$ - \%(crude protein + ash + crude fat + moisture).

The nutritional and fatty acid composition of the total lipid in the stomach contents were determined based on the three main components and the results of their nutritional composition.

\section{Results}

\section{Biological data of fishes}

The biological data of collected fish are given in Table 1. Among the collected female fish, high gonadosomatic indices were present during January and September. The average weight of the fish caught was $8.964 \pm 1.89 \mathrm{~kg}$, with a length of $75.93 \pm 6.29 \mathrm{~cm}$.

The stomach weight of the collected fish was $156.65 \pm 39.60 \mathrm{~g}$, with a stomach content of $76.86 \pm 19.48 \mathrm{~g}$. On average, the stomach was at $49 \%$ of capacity in these fish collected from January to September of 2019. 
Table 1

Biological data of Acha fish (Medialuna ancietae) collected in Pisagua, North of Chile (Latitude: $19^{\circ} 00^{\prime} / 20^{\circ} 00^{\prime}$ and Longitude: 69 $\left.00^{\prime} / 70^{\circ} 30^{\prime}\right)$, during the year 2019.

\begin{tabular}{|c|c|c|c|c|c|c|c|c|}
\hline Date & Sex & $\begin{array}{l}\text { Body } \\
\text { weight } \\
\text { (g) }\end{array}$ & $\begin{array}{l}\text { Stomach } \\
\text { weight (g) }\end{array}$ & $\begin{array}{l}\text { Total } \\
\text { length } \\
\text { (cm) }\end{array}$ & $\begin{array}{l}\text { Stomach } \\
\text { content (g) }\end{array}$ & $\begin{array}{l}\text { Liver weight } \\
\text { (g) }\end{array}$ & $\begin{array}{l}\text { Gonad weight } \\
\text { (g) }\end{array}$ & ISG \\
\hline $\begin{array}{l}\text { January 9, } \\
2019^{1}\end{array}$ & Female & 10909 & 164 & 83 & 80.70 & 130 & 480 & 4.40 \\
\hline April 25, $2019^{2}$ & Female & 11275 & 118.9 & 80 & 58.57 & 139.19 & 162.41 & 1.44 \\
\hline June $11,2019^{2}$ & Female & 8680 & 189.9 & 76 & 93.20 & 107.15 & 69.20 & 0.79 \\
\hline June $12,2019^{2}$ & Female & 8540 & 194.8 & 78 & 95.65 & 100.3 & 65 & 0.76 \\
\hline $\begin{array}{l}\text { September 8, } \\
2019^{2}\end{array}$ & Female & 10300 & 159.4 & 82.5 & 76.19 & 108.9 & 544.55 & 5.28 \\
\hline $\begin{array}{l}\text { November 12, } \\
2019^{1}\end{array}$ & Male & 5350 & 77.5 & 65 & 38.21 & 39.8 & 43.3 & 0.81 \\
\hline $\begin{array}{l}\text { November 13, } \\
2019^{1}\end{array}$ & Female & 8400 & 180.2 & 70 & 89.42 & 75 & 254.6 & 3.03 \\
\hline $\begin{array}{l}\text { November 25, } \\
2019^{1}\end{array}$ & Female & 8265 & 169.1 & 73 & 82.99 & 84.6 & 253.6 & 3.07 \\
\hline \multicolumn{9}{|c|}{ 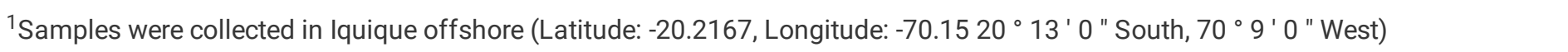 } \\
\hline
\end{tabular}

\section{Collection of reference patterns and stomach content analysis}

Remarkable differences were found when comparing reference slides prepared using the sodium bicarbonate solution method compared with the Castellaro method. The sodium bicarbonate solution maceration technique provided a much more recognizable part of the macroalgae consumed by Acha fish, including greater visibility of the different pigments present in macroalgae (Fig. 1).

Figure 1. Photomicrographs of slide at 40x magnification of macroalge from stomach contents of individuals of Medialuna ancietae prepared with sodium bicarbonate method $1(\mathrm{a}), 1(\mathrm{c}), 1(\mathrm{e})$ and $1(\mathrm{~g})$ compared to reference slides prepared with the sodium bicarbonate method 1(b), 1(d), 1(f) and 1(h).

The main dietary component identified in all individuals was macroalgae, accounting for $96.08 \pm 6.90 \%$. Four different macroalgae were identified in the diet, in addition to incidental components (Table 2). The most abundant and consumed components by all individuals were Lessonia berteroana (formerly known as Lessonia nigrescens), followed by Glossopohora kunthii and Corallina officianalis var. chilensis (Fig. 2). Corallina o. was present only in the first half of the year. Only two components were present in the diet in the second half of the year: macroalgae Lessonia b. and Glossophora k. were identified. 
Table 2

Incidence of the components (wet weight, \%), frecuence of occurrence (FO, \%) and diversity of elements per sample (DES) of the diet in the samples of stomach content of adult individuals of Medialuna ancietae fish collected during the year 2019 in Pisagua, North of Chile (Latitude: $19^{\circ} 00^{\prime} / 20^{\circ} 00^{\prime}$ and Longitude: $69^{\circ} 00^{\prime} / 70^{\circ} 30^{\prime}$ ).

\begin{tabular}{|c|c|c|c|c|c|c|c|c|c|}
\hline Diet component & $\begin{array}{l}\text { Individual } \\
1 \\
\text { January } \\
9,2019\end{array}$ & $\begin{array}{l}\text { Individual } \\
2 \\
\text { April 25, } \\
2019\end{array}$ & $\begin{array}{l}\text { Individual } \\
3 \\
\text { June 11, } \\
2019\end{array}$ & $\begin{array}{l}\text { Individual } \\
4 \\
\text { June 12, } \\
2019\end{array}$ & $\begin{array}{l}\text { Individual } \\
5 \\
\text { September } \\
8,2019\end{array}$ & $\begin{array}{l}\text { Individual } \\
6 \\
\text { November } \\
12,2019\end{array}$ & $\begin{array}{l}\text { Individual } \\
7 \\
\text { November } \\
13,2019\end{array}$ & $\begin{array}{l}\text { Individual } \\
8 \\
\text { November } \\
.25,2019\end{array}$ & FO, \% \\
\hline $\begin{array}{l}\text { Corallina } \\
\text { officinalis var. } \\
\text { Chilensis }\end{array}$ & 0 & 3.72 & 32.83 & 32.02 & 0 & 0 & 0 & 0 & 37.50 \\
\hline $\begin{array}{l}\text { Glossophora } \\
\text { kunthii }\end{array}$ & 32.82 & 31.44 & 16.99 & 16.34 & 30.34 & 61.12 & 65.22 & 67.77 & 100 \\
\hline $\begin{array}{l}\text { Lessonia } \\
\text { berteroana }\end{array}$ & 50.54 & 41.84 & 48.82 & 51.64 & 69.66 & 38.88 & 27.08 & 32.23 & 100 \\
\hline $\begin{array}{l}\text { Macrocystis } \\
\text { integrifolia }\end{array}$ & 0 & 9.69 & 0 & 0 & 0 & 0 & 0 & 0 & 12.5 \\
\hline$\%$ algae & 83.36 & 86.68 & 98.64 & 100 & 100 & 100 & 100 & 100 & \\
\hline $\begin{array}{l}\text { Rhynchocinetes } \\
\text { typus }\end{array}$ & 0 & $8.49 *$ & 0 & 0 & 0 & 0 & 0 & 0 & 12.5 \\
\hline Tegula atra & 0 & $3.55^{\star}$ & $1.36^{\star}$ & 0 & 0 & 0 & 0 & 0 & 25.0 \\
\hline $\begin{array}{l}\text { Phymactis } \\
\text { clematis }\end{array}$ & 16.64 & 0 & 0 & 0 & 0 & 0 & 0 & 0 & 12.5 \\
\hline $\begin{array}{l}\text { Mitrela } \\
\text { unifasciata }\end{array}$ & 0 & $1.27 *$ & 0 & 0 & 0 & 0 & 0 & 0 & 15.8 \\
\hline Patria chilensis & 0 & 0 & 0 & 0 & 0 & 0 & $7.77 *$ & 0 & 12.5 \\
\hline DES & 3 & 7 & 4 & 3 & 2 & 2 & 3 & 2 & \\
\hline
\end{tabular}

\section{Nutritional and fatty acid composition of Acha fish (Medialuna ancietae) stomach content}

Among the three main components identified in the fish's diet, a high ash content was observed, with a greater presence in the red macroalgae Corallina o. (80.9\%), the brown algae Lessonia b., and Glossophora k. presented a similar ash content ( $37 \%$ and $41 \%$, respectively), and high carbohydrate content in both brown algae was also present (Table 3). 
Table 3

Nutritional composition of the main categories identified in the diet of adult Acha fish (Medialuna ancietae). Results (except moisture) are expressed on a "dry matter" basis.

\begin{tabular}{|llll|}
\hline & $\begin{array}{l}\text { Lessonia } \\
\text { berteroana }\end{array}$ & Glossophora & Corallina \\
& & & $\begin{array}{l}\text { Officinalis var. } \\
\text { chilensis }\end{array}$ \\
\hline Protein, \%* & 7.63 & 15.43 & 6.9 \\
\hline Moisture, \% & 9.06 & 9.1 & 2.7 \\
\hline Crude fat, \% & 0.53 & 0.48 & 0.2 \\
\hline Crude fiber & 6.86 & 2.92 & 7.2 \\
\hline Carbohydrates, \% & 45.66 & 33.29 & 9.3 \\
\hline Ash, \% & 37.12 & 41.7 & 80.9 \\
\hline Potassium, \% & 12.38 & 7.35 & 0.394 \\
\hline Sodium, \% & 2.52 & 4.07 & 0.972 \\
\hline Zinc, \% & 17.4 & 0.124 & 0.108 \\
\hline Calcium, \% & 0.86 & 9.08 & 25.84 \\
\hline *Kjeldahl crude protein= \% N x 6.25 & \\
\hline
\end{tabular}

The brown algae showed a similar value in their fat content. The red algae Corallina 0 . showed a lower fat content $(0.2 \%)$ than the brown algae. However, it showed a higher content in polyunsaturated fatty acids $(51.95 \%)$ compared to the brown algae Lessonia b. (with $32.53 \%$ ) and Glossopohora k. (with 39.45\%). The fatty acids with the highest presence in red algae were palmitic saturated fatty acid (16: 0 ) and eicosapentaenoic fatty acid (20:5n3); this red alga also showed a low content of monounsaturated fatty acids with respect to the values shown for brown algae (Table 4). 
Fatty acid profile of the main categories identified in the diet of adult Acha fish (Medialuna ancietae), n-3 fatty acid values are presented in bold. Results are expressed on a "dry matter" basis.

\begin{tabular}{|c|c|c|c|}
\hline & $\begin{array}{l}\text { Lessonia } \\
\text { berteroana }\end{array}$ & $\begin{array}{l}\text { Glossophora } \\
\text { kunthii }\end{array}$ & $\begin{array}{l}\text { Corallina } \\
\text { officinalis } \\
\text { var. chilensis }\end{array}$ \\
\hline Crude fat, $\%$ & 0.53 & 0.48 & 0.20 \\
\hline \multicolumn{4}{|c|}{ Fatty acid profile (expressed as percent of total fatty acids) } \\
\hline UKN & 0.96 & 0.00 & 0.00 \\
\hline UKN & 2.69 & 0.00 & 0.00 \\
\hline Saturated fatty acids & 30.83 & 29.99 & 36.33 \\
\hline Lauric (12:0) & 0.00 & 0.38 & 0.00 \\
\hline Myristic (14:0) & 7.63 & 9.62 & 1.96 \\
\hline C15:0 & 0.00 & 0.58 & 0.00 \\
\hline Palmitic (16:0) & 19.93 & 16.69 & 32.38 \\
\hline Margaric (17:0) & 0.00 & 0.13 & 0.20 \\
\hline Stearic (18:0) & 1.80 & 2.45 & 1.38 \\
\hline Arachidic (20:0) & 1.07 & 0.14 & 0.04 \\
\hline Behenoic (22:0) & 0.22 & 0.00 & 0.00 \\
\hline Lignoceric (24:0) & 0.18 & 0.00 & 0.00 \\
\hline Monounsaturated fatty acids & 23.50 & 30.54 & 11.73 \\
\hline Myristoleic (9c-14:1) & 0.00 & 0.00 & 0.37 \\
\hline Palmitoleic (9c-16:1) & 3.52 & 4.10 & 1.13 \\
\hline $10 c-17: 1$ & 0.69 & 1.08 & 0.25 \\
\hline Elaidic (9t-18:1) & 0.15 & 0.00 & 0.45 \\
\hline Oleic (9c-18:1) & 18.85 & 25.36 & 7.77 \\
\hline Gonodic (20:1n9) & 0.29 & 0.00 & 0.81 \\
\hline Erucic [22:1n9] & 0.00 & 0.00 & 0.77 \\
\hline Nervonic (24:1n9) & 0.00 & 0.00 & 0.55 \\
\hline Polyunsaturated fatty acids & 32.53 & 39.45 & 51.95 \\
\hline Linoleic (18:2n6) & 4.99 & 15.46 & 3.14 \\
\hline Linolenic (18:3n3) & 2.64 & 1.45 & 0.45 \\
\hline g-Linolenic [C18:3n6] & 0.61 & 0.45 & 0.00 \\
\hline Stearidonic (18:4n3) & 2.95 & 0.00 & 0.00 \\
\hline $\mathrm{C} 20: 2$ & 0.00 & 1.08 & 0.44 \\
\hline Homo-a-linolenic(20:3n3) & 0.00 & 0.00 & 0.02 \\
\hline Homo-g-linolenic [C20:3n6] & 0.58 & 0.00 & 0.74 \\
\hline Arachidonic [20:4n6] & 16.54 & 11.86 & 5.84 \\
\hline EPA $(20: 5 n 3)$ & 3.59 & 4.46 & 39.49 \\
\hline
\end{tabular}




\begin{tabular}{|llll|}
\hline & $\begin{array}{l}\text { Lessonia } \\
\text { berteroana }\end{array}$ & $\begin{array}{l}\text { Glossophora } \\
\text { kunthii }\end{array}$ & $\begin{array}{l}\text { Corallina } \\
\text { officinalis } \\
\text { var. chilensis }\end{array}$ \\
\hline C22:2n6 & 0.63 & 0.00 & 0.00 \\
\hline Adrenic [C22:4n6] & 0.00 & 3.63 & 0.33 \\
\hline DPA (22:5n3) & 0.00 & $\mathbf{0 . 3 2}$ & $\mathbf{0 . 7 3}$ \\
\hline DHA (22:6n3) & $\mathbf{0 . 0 0}$ & $\mathbf{0 . 7 4}$ & $\mathbf{0 . 7 7}$ \\
\hline
\end{tabular}

Based on the three main ingredients identified in the diet and its nutritional composition, we found that the diet of the Acha fish is rich in carbohydrates and minerals and has a low protein content.

Among the main fatty acids present in the fish's diet, oleic fatty acid (9c-18:1) was the most abundant. Within the polyunsaturated fatty acids, the results showed a higher presence of arachidonic fatty acid [20:4n6], followed by EPA (20:5n3) and, to a lesser extent, DHA (22:6n3). The fish meat had a low-fat content and was $18.9 \%$ protein (Table 5 ). 
Table 5

Nutritional and fatty acid composition of the total lipid in meat and diet of adult specimens of Acha fish (Medialuna ancietae) compared with nutritional requirements for some fin fish.

\begin{tabular}{|c|c|c|c|}
\hline & Meat** & Medialuna a. diet*** & Requirement for finfish \\
\hline \multirow[t]{4}{*}{ *Protein, \% } & $18.99 \pm 0.26$ & $10.23 \pm 1.94$ & $32-38[32]$ \\
\hline & & & $24-70[33]$ \\
\hline & & & $30-40^{\mathrm{e}}[34]$ \\
\hline & & & $40-45^{f}[34]$ \\
\hline \multirow[t]{2}{*}{ Carbohydrates, \% } & 0 & $34.65 \pm 3.86$ & 12 [32] \\
\hline & & & $20[34]$ \\
\hline Fat, \% & $1.89 \pm 1.68$ & $0.45 \pm 0.04$ & $7-15[34]$ \\
\hline Ash, \% & $1.30 \pm 0.16$ & $40.68 \pm 7.40$ & \\
\hline \multicolumn{4}{|l|}{ Fatty acids $\mathrm{mg} / 100 \mathrm{~g}$} \\
\hline \multirow[t]{2}{*}{ EPA $(20: 5 n 3)$} & $98.05 \pm 2.82$ & $23.95 \pm 9.19$ & $200^{\mathrm{a}} ; 500-750^{\mathrm{b}}$ \\
\hline & & & $500-2000^{g}[34]$ \\
\hline DPA (22:5n3) & $60.41 \pm 2.84$ & $0.74 \pm 0.23$ & \\
\hline DHA (22:6n3) & $109.60 \pm 0.28$ & $1.5619 \pm 0.61$ & $200^{\mathrm{a}} ; 500-750^{\mathrm{b}}[32]$ \\
\hline Arachidonic [20:4n6] & $103.34 \pm 2.34$ & $63.39 \pm 7.77$ & $50^{\mathrm{i}}[35]$ \\
\hline Palmitic (16:0) & $457.05 \pm 4.17$ & $74.35 \pm 21.98$ & \\
\hline Oleic (9c-18:1) & $512.30 \pm 6.92$ & $94.70 \pm 17.72$ & \\
\hline Linoleic (18:2n6) & $21.2 \pm 1.69$ & $42.32 \pm 12.75$ & $1000^{\mathrm{c}} ; 20,000^{\mathrm{d}}[32]$ \\
\hline \multirow[t]{2}{*}{ Linolenic (18:3n3) } & $11.40 \pm 0.14$ & $9.18 \pm 1.22$ & $1000^{c} ; 800-1000^{d}[32]$ \\
\hline & & & $500-1500^{\mathrm{h}}$ \\
\hline Myristic (14:0) & $88.01 \pm 1.55$ & $37.13 \pm 6.53$ & \\
\hline \multicolumn{4}{|c|}{${ }^{\star}$ Kjeldahl crude protein= \% N x 6.25} \\
\hline \multicolumn{4}{|c|}{$\star \star$ Values are based on the mean \pm S.D., $n=3$} \\
\hline \multicolumn{4}{|c|}{ 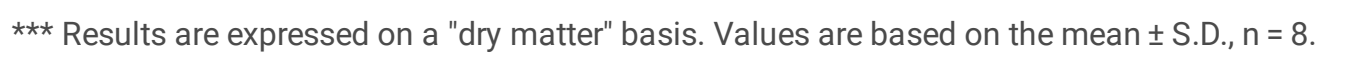 } \\
\hline \multicolumn{4}{|c|}{ [32] ${ }^{a}$ Yellow tail EPA and DHA, ${ }^{b}$ Channel catfish EPA and DHA, ${ }^{c}$ Common carp, ${ }^{d}$ Rainbow trout. } \\
\hline \multicolumn{4}{|c|}{ [34] ${ }^{\mathrm{e}}$ Tilapia, ${ }^{\mathrm{f}}$ Trout and other marine finfish, ${ }^{\mathrm{g}}$ Marine fish, ${ }^{\mathrm{h}}$ Freshwater fish } \\
\hline \multicolumn{4}{|c|}{ [35] ' Malabar red snapper*Kjeldahl crude protein= \% N x 6.25} \\
\hline
\end{tabular}

\section{Discussion}

The different epidermis patterns of the macroalgae associated with the habitat of the $M$. ancietae obtained by the sodium bicarbonate technique allowed us to identify the different plant components of the $M$. ancietae diet. Within the components of the diet of the Acha fish, there is a greater presence of the algae Lessonia b., followed by Glossophora $k$. However, the calcareous red alga Corallina showed an important presence in the first semester of the year in females, with a low gonadosomatic index. Of the total components found in the fish's diet, $96 \%$ correspond to macroalgae, so our results show that $M$. ancietae is an herbivore fish [7]. Our results are consistent with 
studies carried out in species of the same genus, the halfmoon (Medialuna californiensis: Kyphosidae), a herbivorous fish in the temperate waters of California [6,36]. The macroalgae identified in the diet of the $M$. ancietae fish are low in fat; this fat showed a higher presence of polyunsaturated fatty acids $(41.31 \%)$, followed by saturated fatty acids $(32.38 \%)$ with a higher presence of palmitic and myristic fatty acids and to a lesser extent, monounsaturated fatty acids (21.92\%), with a higher presence of oleic fatty acid. These proportions are similar to those found for fish oil with a greater presence of polyunsaturated fatty acids followed by saturated fatty acids (with a high presence of palmitic fatty acid) and in relation to the monounsaturated ones with a greater presence of oleic fatty acid [37]. The polyunsaturated fatty acid with a higher presence in the components of the diet was arachidonic, follow by eicosapentaenoic and docosahexaeoic, except Corallina of., which showed a high percentage of EPA. This unexpected high EPA content may be related to the presence of diatoms observed in the Corallina of. samples or by the presence of marine cryptophytes [38]. Our studies showed an ARA/EPA ratio of 2.64 for the Medialuna fish diet; this ratio is much higher when compared to fish oil (0.15)[39].

Carbohydrates $(34.65 \%)$ and minerals $(40.68 \%)$ were the most abundant nutrients in the diet of $M$. ancietae, with important contributions of calcium from Corallina of. and zinc from Lessonia $b$.

The $M$. ancietae diet was low in protein $(10.23 \%)$. The contribution of minerals was relatively higher in the summer months due to the presence of Corallina, which presented a high ash content (80.9\%). Our data shows that the diet of this herbivorous species is $13-60 \%$ lower in protein than the protein requirements reported for other species [33]. Nutritional and fatty acid composition of the total lipid in diet of adult specimens of Acha fish differ from those of commercially produced feeds or nutritional requirements reported for other marine and freshwater non-herbivorous fish species. Most of the nutrients present in the Medialuna diet are found at lower levels, including EPA (20:5n3) and DHA (22:6n3) [34]. Most fed aquaculture species rely on wild-captured fish for these essential fatty acids [4], while $M$. ancietae can obtain and has the ability to concentrate these essential fatty acids from potentially cultivable macroalgae [40, 41]. M. ancietae meat can provide $268 \mathrm{mg} / 100 \mathrm{~g}$ of the essential $\mathrm{n}-3$ long-chain polyunsaturated fatty acids (EPA + DPA + DHA).

The protein content present in the meat of $M$. ancietae $(18.99 \pm 0.26 \%)$ is high considering the reported protein range of $8.2-23.9 \mathrm{~g} / 100$ $\mathrm{g}$ for some freshwater and marine fish. In terms of fat (1.89 $\pm 1.68 \%), M$. ancietae is considered a lean fish [42]. Our results showed a high protein content in $M$. ancietae meat and the presence of less protein (13-60\%) in their diet when compared with the protein requirements of other non-herbivorous fish species demonstrating that $M$. ancietae is an efficient converter of feed into protein with no fish feed biomass needed.

\section{Conclusions}

Mycohistology of the stomach contents of $M$. ancietae allowed us to identify the components of the diet; this method also allowed us to obtain a reference pattern based on the epidermis of collected aquatic plants. The results of our study show that the $M$. ancietae fish of Northern Chile is an herbivore species. Adult fish of the M. ancietae diet consists of more than $90 \%$ of macroalgae, mostly of Lessonia bertorana, Glossosphora kuntii, and Corallina officinalis var. chilensis. Medialuna eating habits are rich in carbohydrates and low in protein content. Minerals are of great importance in the fish's diet, especially in the first months of the year.

Compared to non-herbivorous fish our results showed that most of the nutrients present in the Medialuna diet are found at much lower levels, including EPA and DHA (49.7\%) and protein (13-60\%). Most fed aquaculture non-herbivorous species rely on wild-captured fish for these essential nutrients, while $M$. ancietae can obtain and has the ability to concentrate them from potentially cultivable macroalgae.

The requirements for protein, fat and long-chain polyunsaturated fatty acids for $M$. ancietae are low and completely fish-free compared with non-herbivorous fish species that have been studied. Analyses of the eating habits of $M$. ancietae and the nutritional quality of its meat allow us to conclude that this species has potential for use in the development of sustainable aquaculture by easing pressure on existing wild fish stocks and contribute to nutrition security in North of Chile.

\section{Declarations}

\section{Acknowledgements}

The authors thank the Martinez Varas family of divers from the town of Pisagua for their support in catching the fish and collecting the algae that made this research possible.

Page $11 / 15$ 


\section{Funding}

This work was supported by the Agencia Nacional de Investigación y Desarrollo, FONDEF [grant number ID18110292].

\section{Author contributions}

Conceptualization, Giorgio Castellaro, German Bueno, Jurij Wacyk and Ivonne Lozano-Muñoz; Investigation, German Bueno, Ivonne Lozano-Muñoz; Methodology, Ivonne Lozano-Muñoz and Giorgio Castellaro; Resources, German Bueno and Jurij Wacyk; Writing-original draft, Ivonne Lozano-Muñoz; Writing-review \& editing Ivonne Lozano-Muñoz, Giorgio Castellaro and German Bueno.

\section{Conflict of Interest}

The authors declare that they have no conflict of interest.

\section{Data availability statement}

The datasets generated during and/or analysed during the current study are available from the corresponding author on reasonable request.

\section{References}

1. Salin, K. R. \& Ataguba, G. A. Aquaculture and the environment: Towards sustainability. In Sustainable Aquaculture;Springer, 2018;pp. 1-62.

2. de la Lara, E., Boyland, N. F. \& Welfare An NGO's Point of View. In Proceedings of the dA Derecho Animal: Forum of Animal Law Studies; 2019; Vol. 10, pp. 0077-0084.

3. Shah, M. R. et al. Microalgae in Aquafeeds for a Sustainable Aquaculture Industry.J. Appl. Phycol.2018, 30,197-213.

4. Froehlich, H. E., Jacobsen, N. S., Essington, T. E., Clavelle, T. \& Halpern, B. S. Avoiding the Ecological Limits of Forage Fish for Fed Aquaculture.Nat. Sustain.2018, 1,298-303, doi:10.1038/s41893-018-0077-1.

5. Andrew, N. L. \& Jones, G. P. Patch Formation by Herbivorous Fish in a Temperate Australian Kelp Forest.Oecologia1990, 85,57-68.

6. Bredvik, J. J., Boerger, C. \& Allen, L. G. Age and Growth of Two Herbivorous, Kelp Forest Fishes, the Opaleye (Girella Nigricans) and Halfmoon (Medialuna Californiensis). Bull. South. Calif. Acad. Sci.2011, 110,25-34.

7. Horn, M. H. Biology of Marine Herbivorous Fishes. Ocean. Mar Bio/1989, 27,167-272.

8. Flores, H., Rendíc, J. C. \& Alimenticia Supervivencia y Crecimiento de Juveniles Silvestres de Graus Nigra Philippi, 1887 En Cautiverio (Perciformes: Kyphosidae).Lat. Am. J. Aquat. Res.2011, 39,607-612.

9. Godoy, N., Gelcich, S., Vásquez, J. A. \& Castilla, J. C. Spearfishing to Depletion: Evidence from Temperate Reef Fishes in Chile.Ecol. Appl.2010, 20,1504-1511.

10. Schiel, D. R. \& Foster, M. S. The Biology and Ecology of Giant Kelp Forests; Univ of California Press 2015; ISBN 978-0-520-27886-8.

11. Pinochet, R. et al. Selección Dietaria de Tegula Atra (Lesson, 1830) Como Una Aproximación de Preferencia Sobre Distintas Especies de Macroalgas En El Sur de Chile.An. Inst. Patagon.2018, 46,51-60, doi:10.4067/S0718-686X2018000300051.

12. Ahumada, J. F. \& Paredes, G. M.INSTITUTO DE FOMENTO PESQUERO, IFOP 2002.

13. Parvez, S., Rahman, A., Mufty, M. \& Zahangir, A. Feeding Behavior and Growth Performance of Tade Mullet, Liza Tade (Forsskail, 1775) in Brackish Water Gher Farming System.Int. J. Adv. Chem. Eng. Biol. Sci.2017, 4,59-64, doi:10.15242/IJACEBS.AE12164045.

14. Rainuzzo, J. R., Reitan, K. I. \& Olsen, Y. The Significance of Lipids at Early Stages of Marine Fish: A Review.Aquaculture1997, $155,103-115$.

15. Izquierdo, M. S., Fernandez-Palacios, H. \& Tacon, A. G. J. Effect of Broodstock Nutrition on Reproductive Performance of Fish.Aquaculture2001, 197,25-42.

16. Castellaro, G., Squella, G., Ullrich, N. F., León, R. T. \& Raggi, C. F. S, A. Algunas Técnicas Microhistolóigcas Utilizadas En La Determinación de La Composición Botánica de Dietas de Herbívoros.Agric. Téc.2007, 67,86-93, doi:10.4067/S0365-

28072007000100011.

Page $12 / 15$ 
17. Kilkenny, C., Browne, W. J., Cuthill, I. C., Emerson, M. \& Altman, D. G. Improving Bioscience Research Reporting: The ARRIVE Guidelines for Reporting Animal Research.PLoS Biol.2010, 8,e1000412, doi:10.1371/journal.pbio.1000412.

18. Quiroz-González, N. et al. Biodiversidad de Algas Rojas Marinas (Rhodophyta) En Tabasco, México.Acta Botánica Mex. 2018,103120, doi:10.21829/abm123.2018.1253.

19. Dacar, M. A. \& Giannoni, S. M. A Simple Method for Preparing Reference Slides of Seed.J. Range Manag.2001,191-193.

20. Tapia, L. GUIA DE BIODIVERSIDAD 2002.

21. Etcheverry, H. Algas Ben Tonic As de Chile 2015.

22. Velásquez, C., Martín, C. S., Jaramillo, E. \& Camus, P. A. catÁLoGo microHistoLóGico dE macrófitas acuÁticas dE dos HumEdaLEs costEros dE cHiLE: uNa HErramiENta para Estudios tróficos EN avEs acuÁticas HErBívoras. 2018, 6.

23. Guiry, M. D. Algaebase:: Listing the World's Algae Available online: http://www.algaebase.org/ (accessed on 9 July 2019 ).

24. Hyslop, E. J. Stomach Contents Analysis-a Review of Methods and Their Application.J. Fish Biol.1980, 17,411-429.

25. Chemists, A. O. A. C. A. of O.A. AOAC Official Method 996.06 Analysis of Methyl Esters by Capillary GLC 2012.

26. Chemists, A. O. A. C. A. of O.A. Protein (Crude) in Animal Feed and Pet Food 984.13.Off. Methods Anal. Off. Anal. Chem. Int.1995, 1,30-31.

27. Chemists, A. O. A. C. A. of O.A. AOAC Official Method 920.39 Crude Fat in Animal Feed.

28. Chemists, A. O. A. C. A. of O.A. AOAC Official Method 934.01 Loss on Drying (Moisture) at 95-100oC for Feeds 2000.

29. Chemists, A. O. A. C. A. of O.A. AOAC Official Method 942.05 Determinaton of Ash in Animal Feed. 2012,1392-1397.

30. Chemists, A. O. A. C. A. of O.A. AOAC Official Method 969.23 Sodium and Postassium in Seafood (Flame Photome, 1971).

31. Chemists, A. O. A. C. A. of O.A. AOAC Official Method 968.08 Minerals in Animal Feed and Pet Food 1996.

32. Prabu, E., Felix, S., Felix, N., Ahilan, B. \& Ruby, P. An Overview on Significance of Fish Nutrition in Aquaculture Industry.Int. J. Fish. Aquat. Stud.2017, 5,349-355.

33. Teles, A. O., Couto, A., Enes, P. \& Peres, H. Dietary Protein Requirements of Fish - a Meta-Analysis.Rev. Aquac.2020, 12,1445-1477, doi:https://doi.org/10.1111/raq.12391.

34. Craig, S., Helfrich, L., Kuhn, D. D. \& Schwarz, M. H. erstanding Fish Nutrition, Feeds, and Feeding 2017.

35. Chee, W. L., Turchini, G. M., Teoh, C. Y. \& Ng, W. K. Dietary Arachidonic Acid and the Impact on Growth Performance, Health and Tissues Fatty Acids in Malabar Red Snapper (Lutjanus Malabaricus) Fingerlings.Aquaculture2020, 519,734757, doi:10.1016/j.aquaculture.2019.734757.

36. Boerger, C. M. \& Life History Diet and Production of an Herbivorous Temperate Marine Fish, Medialuna Californiensis (Family: Kyphosidae). PhD Thesis, California State University, Northridge 2011.

37. FATTY ACID COMPOSITION OF FISH OILS.Nutr. Rev.2009, 23,51-52, doi:10.1111/j.1753-4887.1965.tb02073.x.

38. Peltomaa, E., Johnson, M. D. \& Taipale, S. J. Marine Cryptophytes Are Great Sources of EPA and DHA.Mar. Drugs2018, 16, 3, doi:10.3390/md16010003.

39. Lozano, I., Wacyk, J. M., Carrasco, J. \& Cortez-San Martín, M. A. Red Macroalgae Pyropia Columbina and Gracilaria Chilensis: Sustainable Feed Additive in the Salmo Salar Diet and the Evaluation of Potential Antiviral Activity against Infectious Salmon Anemia Virus.J. Appl. Phycol.2016, 28,1343-1351.

40. Camus, C. \& Buschmann, A. H. Aquaculture in Chile: What about Seaweeds. World Aquac. March2017,40-42.

41. Westermeier, R., Murúa, P., Patiño, D. J., Muñoz, L. \& Müller, D. G. Holdfast Fragmentation of Macrocystis Pyrifera (Integrifolia Morph) and Lessonia Berteroana in Atacama (Chile): A Novel Approach for Kelp Bed Restoration.J. Appl. Phycol.2016, 28,2969-2977.

42. Mohanty, B. P. et al. Nutritional Composition of Food Fishes and Their Importance in Providing Food and Nutritional Security. Food Chem.2019, 293,561-570, doi:10.1016/j.foodchem.2017.11.039.

\section{Figures}




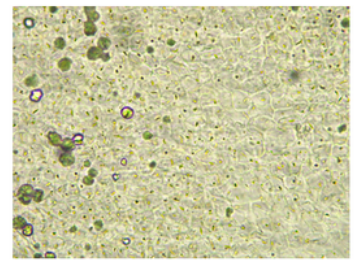

1(a)

Glossophora kunthii

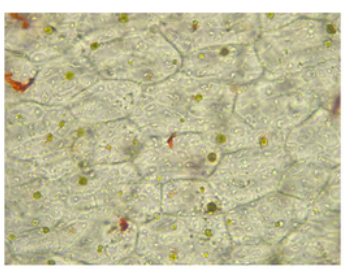

1(c)

Lessonia berteroana

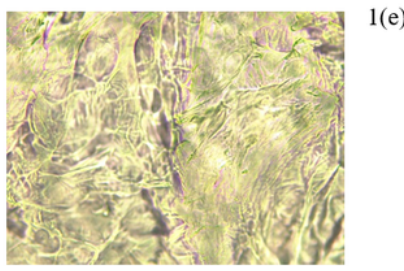

Corallina officinalis var. Chilensis

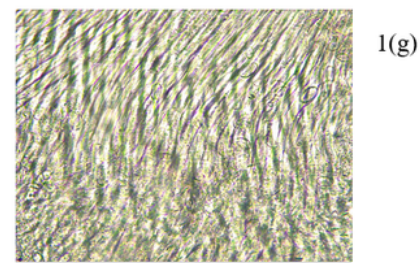

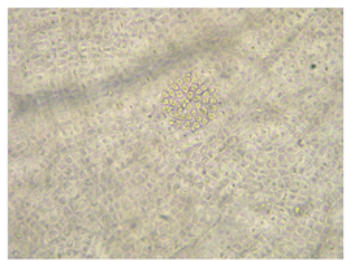

$1(\mathrm{~d})$

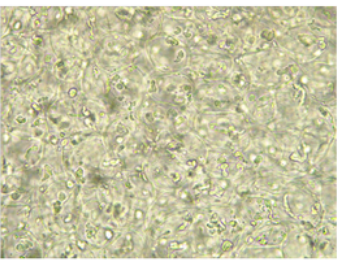

1(b)

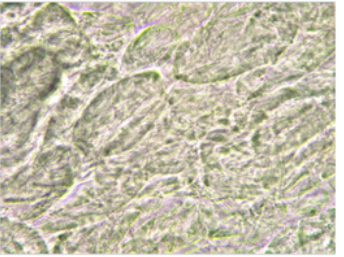

1(f)

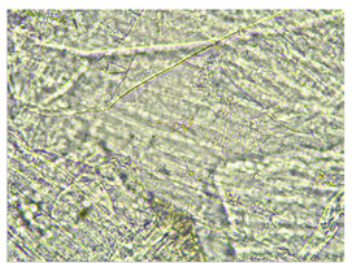

$1(\mathrm{~h})$

\section{Figure 1}

Photomicrographs of slide at 40x magnification of macroalge from stomach contents of individuals of Medialuna ancietae prepared with sodium bicarbonate method $1(\mathrm{a}), 1(\mathrm{c}), 1(\mathrm{e})$ and $1(\mathrm{~g})$ compared to reference slides prepared with the sodium bicarbonate method $1(b), 1(d), 1(f)$ and 1(h). 


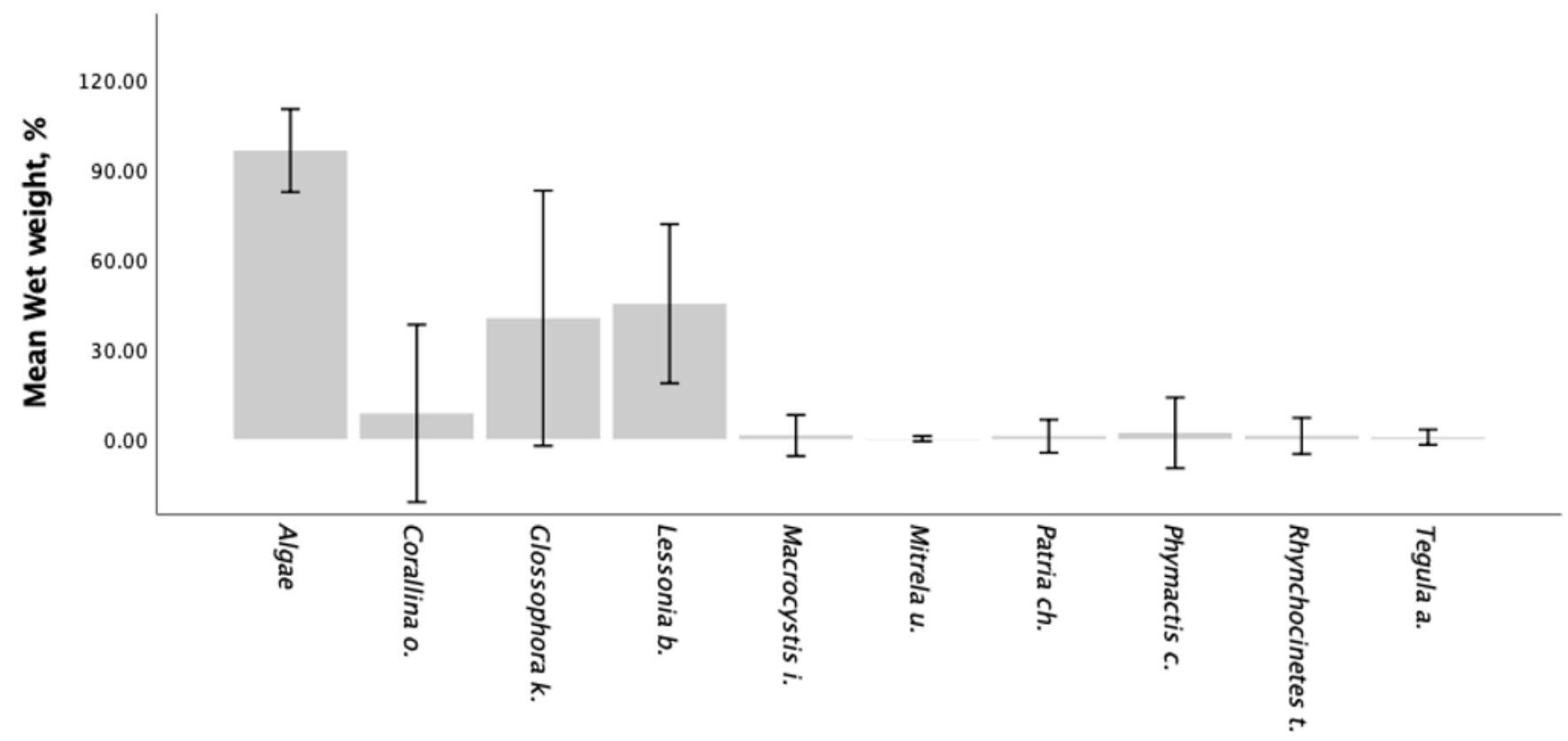

Dietary categories

\section{Figure 2}

Composition of stomach content of Acha fish (Medialuna ancietae) colected in Pisagua, North of Chile (Latitude: $19^{\circ} 00^{\prime} / 20^{\circ} 00^{\prime}$ and Longitude: $69^{\circ} 00^{\prime} / 70^{\circ} 30^{\prime}$ ), during the year 2019. Broodstock diet expressed as a gravimetric percentage (wet weight). Values are based on the mean \pm S.D. a) and mean \pm S.E b) and c) $n=8$. 